\title{
Next-generation sequencing of tissue
}

\author{
A logical extension
}

\section{OPEN}

Joseph R. Berger, MD

Michael R. Wilson, MD

Correspondence to Dr. Berger:

joseph.berger@uphs.upenn.edu

Neurol Neuroimmunol

Neuroinflamm

2016;3:e261; doi: 10.1212/

NXI.0000000000000261

\section{See article}

In this issue of Neurology ${ }^{\circledR}$ Neuroimmunology \& Neuroinflammation, Salzberg et $\mathrm{al}^{1}$ report on the results of a small prospective study of the application of nextgeneration sequencing (NGS) of RNA and DNA extracted from brain biopsy tissue specimens obtained from 10 patients with suspected neuroinfectious disease processes. In 3 patients, the NGS results, which included JC virus, Epstein-Barr virus, and Mycobacterium tuberculosis, were validated by other measures. Standard diagnostic methods would have led to the correct diagnosis in these patients; however, the NGS results showed that the same conclusions could have been drawn from a single assay that is able to detect bacteria, fungi, parasites, and viruses simultaneously. In 2 patients, the NGS results were indeterminate, but raised the possibility of infectious organisms that had not been suspected clinically: possible Delftia acidovorans in a 69-year-old man with Tolosa-Hunt syndrome and pachymeningitis and Elizabethkingia spp. from the brain mass of a 19-year-old man with Fanconi anemia. ${ }^{1}$ In 5 other cases, the investigators found NGS clinically useful, such as ruling out the presence of an infection in suspected cases of sarcoidosis or glial tumors, ${ }^{1}$ although the actual negative predictive value of a negative NGS result awaits definition in a larger prospective study.

The cost of performing NGS and analyzing the data, which can be accomplished in as little as 48 hours, ${ }^{2}$ is currently estimated at $\$ 2,000-\$ 5,000 /$ sample and will almost certainly continue to decline with refinements in methodology and advances in sequencing technology. NGS has broad potential applications, including the identification of pathogens, improving tumor classification, ${ }^{3,4}$ identifying genetic disorders in newborns, ${ }^{5}$ and a myriad of other potential applications. The use of NGS in identifying difficult-to-diagnose infectious diseases of the nervous system has included the identification of such pathogens as Leptospria spp. ${ }^{2}$ and Balamuthia mandrillaris ${ }^{6}$ in the CSF of patients with meningoencephalitis. A novel astrovirus, ${ }^{7,8}$ variegated squirrel bornavirus, ${ }^{9}$ and $M$ tuberculosis $^{10}$ have also been identified in solid tissue specimens, including brain biopsies. This series adds to this small but growing literature.

Infectious diseases of the nervous system are often difficult to diagnose. Although most meningitis results from an infectious pathogen, epidemiologic studies suggest that the causative organism remains undetected in between $15 \%$ and $60 \%$ of cases. ${ }^{11-13}$ Similarly, there are more than 100 infectious pathogens that have been associated with encephalitis, ${ }^{14}$ but in only $40 \%-70 \%$ is an etiology established. ${ }^{15-17}$ The relatively high number of patients in whom a pathogen cannot be identified has been attributed to suboptimal testing and a lack of tests for all the potential pathogens. ${ }^{16}$ Frequently, empiric treatment is instituted despite the absence of an identified pathogen, resulting in inadequate or inappropriate treatment and potentially dangerous delays in diagnosis.

Despite the higher yield in recognizing infectious pathogens from brain and spinal abscesses, even the availability of tissue does not ensure a diagnosis. ${ }^{18}$ Some series state that stereotactic biopsy is nondiagnostic in $2 \%-15 \%$ of patients, ${ }^{19}$ but in one recent series of 100 patients undergoing stereotactic biopsy, 24 specimens proved to be nondiagnostic. ${ }^{20}$ Smaller lesions $\left(<1 \mathrm{~cm}^{3}\right)$ have lower diagnostic yields. ${ }^{21}$ Often the nondiagnostic biopsy is the consequence of inadequate tissue sampling.

The application of NGS to these tissue specimens will almost certainly increase the ability to detect an offending microorganism, but the 2 indeterminate cases in this series also highlight the potential pitfalls of such a broad brush, hypothesis-free assay. Bacterial sequences are omnipresent in unbiased, metagenomic NGS datasets as a result of sample and laboratory contamination. ${ }^{22,23}$ Indeed, Delftia acidovorans was present in the NGS results of a number of the other subjects in this case series, but in those cases, it was considered to be a contaminant. In addition, Elizabethkingia spp. frequently appears as a contaminant in metagenomic NGS datasets as well. Without a negative control like a water sample accompanying each

From the Department of Neurology (J.R.B.), Perelman School of Medicine, University of Pennsylvania, Philadelphia; and the Department of Neurology (M.R.W.), University of California San Francisco.

Funding information and disclosures are provided at the end of the editorial. Go to Neurology.org/nn for full disclosure forms.

This is an open access article distributed under the terms of the Creative Commons Attribution-NonCommercial-NoDerivatives License 4.0 (CC BY-NC-ND), which permits downloading and sharing the work provided it is properly cited. The work cannot be changed in any way or used commercially. 
sequencing run, it can be very difficult to discriminate between infection and contamination.

For metagenomic NGS to move from the research laboratory to the clinical laboratory, the field as a whole needs to develop rigorous criteria for determining whether a microbe present in the NGS data was an infection. The Food and Drug Administration recently issued guidance on this issue (http://www.fda.gov/downloads/ MedicalDevices/DeviceRegulationandGuidance/ GuidanceDocuments/UCM500441.pdf). Indeed, identifying sequences in a dataset that align to a particular organism is only the start of the analysis. One must then investigate the specificity with which those reads align to that organism and not to any others. In addition, the extent of genomic coverage must be evaluated. A 100- to 200-nucleotide sequence aligning to an organism is much less convincing for infection than when one can find sequences covering much of the organism's genome. Finally, NGS is semiquantitative, and a high abundance of reads to an organism relative to the typical background levels seen in other samples can also be suggestive of a real infection vs contamination. ${ }^{24}$ Once the analysis of the NGS data was complete, orthogonal assays are critical for confirming the presence of a particular pathogen, including culture, 16s ribosomal RNA PCR, immunohistochemistry, serology, and, if appropriate, electron microscopy. Finally, placing all the results into the particular patient's clinical context is also crucial.

Because metagenomic NGS attempts to sequence all of the nucleic acid in a sample by using random hexamer primers, it may uncover totally unanticipated associations between diseases of unknown etiology and a specific pathogen. Examples of the latter that predate the NGS sequencing era include Whipple disease, now recognized to be the consequence of the bacterium Tropheryma whipplei, ${ }^{25}$ and tropical spastic paraparesis, recognized to be the consequence of a retrovirus, human T-lymphotropic virus (HTLV) type $\mathrm{I}^{26}$ (and less often, type II), and currently referred to as HTLV-associated myelopathy.

As the accessibility of NGS increases, there will almost certainly be a large and growing contingent of patients for whom NGS will be performed. The preliminary studies on brain tissue reported in this issue add to the existing literature and highlight the need for larger studies to rigorously characterize the performance characteristics of the assay across an array of tissue types and organisms.

\section{STUDY FUNDING}

No targeted funding reported.

\section{DISCLOSURE}

J. Berger served as a consultant and/or on the PML adjudication committees of Amgen, AstraZeneca, Millennium/Takeda, and Pfizer; received travel funding and/or speaker honoraria from PML consortium, Forward
Pharmaceuticals; is an associate editor for Journal of Neurovirology; is on the editorial board for ISRN Education, Neuroscience, World Journal of Rheumatology, and Multiple Sclerosis and other related disorders; receives royalties from Elsevier; has consulted for Amgen, AstraZeneca, Bayer, Biogen, Eisai, EMD Serono, Forward Pharmaceuticals, Genentech/ Roche, Genzyme, Inhibikase, Millenium/Takeda, Novartis, Johnson \& Johnson, Pfizer, and Sanofi Aventis; and participated in legal proceedings for Biogen. M.R. Wilson received research support from NIH/NCATS, American Brain Foundation Clinical Research Training Fellowship. Go to Neurology.org/nn for full disclosure forms.

\section{REFERENCES}

1. Salzberg SL, Breitwieser FP, Kumar A, et al. Next-generation sequencing in neuropathologic diagnosis of infections of the nervous system. Neurol Neuroinflamm Neuroimmunol 2016;3:e251. doi: 10.1212/NXI.0000000000000251.

2. Wilson MR, Naccache SN, Samayoa E, et al. Actionable diagnosis of neuroleptospirosis by next-generation sequencing. N Engl J Med 2014;370:2408-2417.

3. Johansen Taber KA, Dickinson BD, Wilson M. The promise and challenges of next-generation genome sequencing for clinical care. JAMA Intern Med 2014;174:275-280.

4. Pentsova EI, Shah RH, Tang J, et al. Evaluating cancer of the central nervous system through next-generation sequencing of cerebrospinal fluid. J Clin Oncol 2016;34: 2404-2415.

5. Friedman E. Next-generation sequencing for newborn screening: are we there yet? Genet Res 2015;97:e17.

6. Wilson MR, Shanbhag NM, Reid MJ, et al. Diagnosing Balamuthia mandrillaris encephalitis with metagenomic deep sequencing. Ann Neurol 2015;78:722-730.

7. Fremond ML, Perot P, Muth E, et al. Next-generation sequencing for diagnosis and tailored therapy: a case report of astrovirus-associated progressive encephalitis. J Pediatr Infect Dis Soc 2015;4:e53-e57.

8. Naccache SN, Peggs KS, Mattes FM, et al. Diagnosis of neuroinvasive astrovirus infection in an immunocompromised adult with encephalitis by unbiased next-generation sequencing. Clin Infect Dis 2015;60:919-923.

9. Hoffmann B, Tappe D, Hoper D, et al. A variegated squirrel bornavirus associated with fatal human encephalitis. New Engl J Med 2015;373:154-162.

10. Das S, Roychowdhury T, Kumar P, et al. Genetic heterogeneity revealed by sequence analysis of Mycobacterium tuberculosis isolates from extra-pulmonary tuberculosis patients. BMC Genomics 2013;14:404.

11. Guan H, Shen A, Lv X, et al. Detection of virus in CSF from the cases with meningoencephalitis by nextgeneration sequencing. J Neurovirol 2016;22:240-245.

12. Jarrin I, Sellier P, Lopes A, et al. Etiologies and management of aseptic meningitis in patients admitted to an internal medicine department. Medicine 2016;95:e2372.

13. Takhar SS, Ting SA, Camargo CA Jr, Pallin DJ. U.S. emergency department visits for meningitis, 1993-2008. Acad Emerg Med 2012;19:632-639.

14. Venkatesan A, Tunkel AR, Bloch KC, et al. Case definitions, diagnostic algorithms, and priorities in encephalitis: consensus statement of the international encephalitis consortium. Clin Infect Dis 2013;57:1114-1128.

15. George BP, Schneider EB, Venkatesan A. Encephalitis hospitalization rates and inpatient mortality in the United States, 2000-2010. PLoS One 2014;9:e104169.

16. Polage CR, Cohen SH. State-of-the-art microbiologic testing for community-acquired meningitis and encephalitis. J Clin Microbiol 2016;54:1197-1202. 
17. Vora NM, Holman RC, Mehal JM, Steiner CA, Blanton J, Sejvar J. Burden of encephalitis-associated hospitalizations in the United States, 1998-2010. Neurology 2014;82:443-451.

18. Gelfand JM, Genrich G, Green AJ, Tihan T, Cree BA. Encephalitis of unclear origin diagnosed by brain biopsy: a diagnostic challenge. JAMA Neurol 2015;72:66-72.

19. Air EL, Warnick RE, McPherson CM. Management strategies after nondiagnostic results with frameless stereotactic needle biopsy: retrospective review of 28 patients. Surg Neurol Intern 2012;3:S315-S319.

20. Zoeller GK, Benveniste RJ, Landy H, Morcos JJ, Jagid J. Outcomes and management strategies after nondiagnostic stereotactic biopsies of brain lesions. Stereotact Funct Neurosurg 2009;87:174-181.

21. Waters JD, Gonda DD, Reddy H, Kasper EM, Warnke PC, Chen CC. Diagnostic yield of stereotactic needle-biopsies of sub-cubic centimeter intracranial lesions. Surg Neurol Int 2013;4:S176-S181.
22. Lee D, Das Gupta J, Gaughan C, et al. In-depth investigation of archival and prospectively collected samples reveals no evidence for XMRV infection in prostate cancer. PLoS One 2012;7:e44954.

23. Naccache SN, Greninger AL, Lee D, et al. The perils of pathogen discovery: origin of a novel parvovirus-like hybrid genome traced to nucleic acid extraction spin columns. J Virol 2013;87:11966-11977.

24. Wylie KM, Blanco-Guzman M, Wylie TN, et al. Highthroughput sequencing of cerebrospinal fluid for diagnosis of chronic Propionibacterium acnes meningitis in an allogeneic stem cell transplant recipient. Transpl Infect Dis 2016;18:227-233.

25. Fenollar F, Lagier JC, Raoult D. Tropheryma whipplei and Whipple's disease. J Infect 2014;69:103-112.

26. Gessain A, Saal F, Gout O, De-The G, Peries J. HTLV-I virus and associated chronic neuromyelopathies: current data and hypotheses [in French]. Nouv Rev Fr Hematol 1988;30:15-20. 


\section{Neurology \\ Neuroimmunology \& Neuroinflammation}

Next-generation sequencing of tissue: A logical extension

Joseph R. Berger and Michael R. Wilson

Neurol Neuroimmunol Neuroinflamm 2016;3;

DOI 10.1212/NXI.0000000000000261

This information is current as of July 14, 2016

\section{Updated Information \& Services}

References

Citations

Subspecialty Collections

Permissions \& Licensing

Reprints including high resolution figures, can be found at:

http://nn.neurology.org/content/3/4/e261.full.html

This article cites 26 articles, 3 of which you can access for free at: http://nn.neurology.org/content/3/4/e261.full.html\#\#ref-list-1

This article has been cited by 1 HighWire-hosted articles: http://nn.neurology.org/content/3/4/e261.full.html\#\#otherarticles

This article, along with others on similar topics, appears in the following collection(s):

All Infections

http://nn.neurology.org//cgi/collection/all_infections

Information about reproducing this article in parts (figures,tables) or in its entirety can be found online at:

http://nn.neurology.org/misc/about.xhtml\#permissions

Information about ordering reprints can be found online: http://nn.neurology.org/misc/addir.xhtml\#reprintsus

Neurol Neuroimmunol Neuroinflamm is an official journal of the American Academy of Neurology.

Published since April 2014, it is an open-access, online-only, continuous publication journal. Copyright $(\subset$ 2016 American Academy of Neurology. All rights reserved. Online ISSN: 2332-7812.

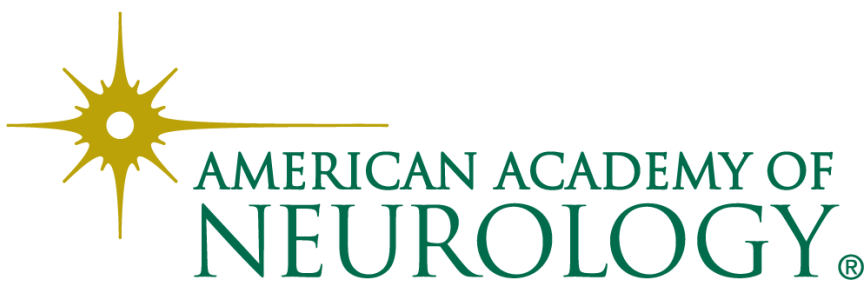

